
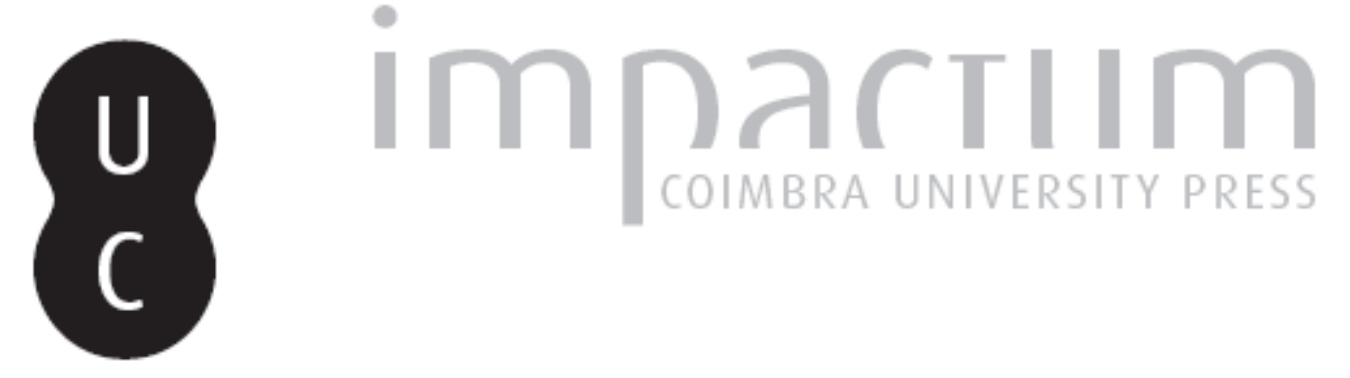

\title{
Discriminação no discurso: análise da representação de refugiados em Público através da gramática visual de Kress e Van Leeuwen
}

Autor(es): $\quad$ Empinotti, Marina Lisboa

Publicado por: Imprensa da Universidade de Coimbra

URL persistente:

URI:http://hdl.handle.net/10316.2/43229

DOI:

DOI:2183-5462 (digital); DOI:https://doi.org/10.14195/2183-5462_31_7

Accessed : $\quad$ 26-Apr-2023 15:31:08

A navegação consulta e descarregamento dos títulos inseridos nas Bibliotecas Digitais UC Digitalis, UC Pombalina e UC Impactum, pressupõem a aceitação plena e sem reservas dos Termos e Condições de Uso destas Bibliotecas Digitais, disponíveis em https://digitalis.uc.pt/pt-pt/termos.

Conforme exposto nos referidos Termos e Condições de Uso, o descarregamento de títulos de acesso restrito requer uma licença válida de autorização devendo o utilizador aceder ao(s) documento(s) a partir de um endereço de IP da instituição detentora da supramencionada licença.

Ao utilizador é apenas permitido o descarregamento para uso pessoal, pelo que o emprego do(s) título(s) descarregado(s) para outro fim, designadamente comercial, carece de autorização do respetivo autor ou editor da obra.

Na medida em que todas as obras da UC Digitalis se encontram protegidas pelo Código do Direito de Autor e Direitos Conexos e demais legislação aplicável, toda a cópia, parcial ou total, deste documento, nos casos em que é legalmente admitida, deverá conter ou fazer-se acompanhar por este aviso.

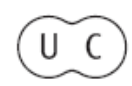




\section{Media Jornalismo}

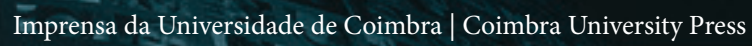

N. 31 Vol. 17, N. ${ }^{\circ} 2$ - 2017

Esia

(2) M MEDIA E DIVERSIDADE

लिखिएक

2)

*).

() (6) $3(9)$

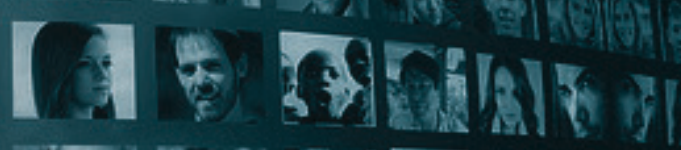

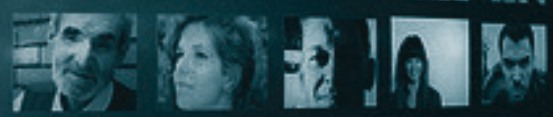

* a

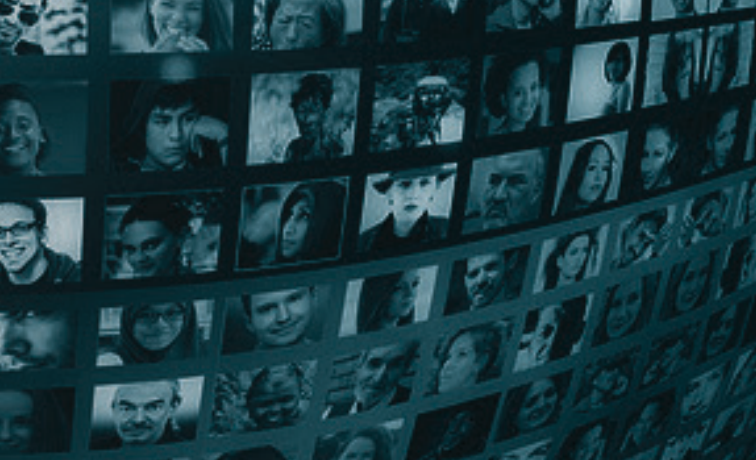

तथ 


\title{
DISCRIMINAÇÃO NO DISCURSO: ANÁLISE DA REPRESENTAÇÃO DE REFUGIADOS NO PÚBLICO ATRAVÉS DA GRAMÁTICA VISUAL DE KRESS E VAN LEEUWEN
}

\author{
DISCRIMINATION IN DISCOURSE: USING KRESS AND \\ VAN LEEUWEN'S VISUAL GRAMMAR TO ANALYZE THE \\ DEPICTION OF REFUGEES IN PÚBLICO
}

\author{
MARINA LISBOA EMPINOTTI \\ Universidade da Beira Interior, 6201-001 Covilhã, Portugal \\ marinaempinotti@gmail.com
}

\section{Resumo}

Segundo o Alto Comissariado das Nações Unidas para os Refugiados, em 2015, quase um milhão de pessoas, vindas de países como Líbia, Síria, Iraque, e nações africanas politicamente instáveis, arriscaram-se na travessia do mar Mediterrâneo para tentar uma vida melhor como refugiadas na Europa. Este fluxo populacional foi um dos assuntos mais presentes nos media europeus durante 0 ano. Este trabalho recorre às categorias da gramática visual de Kress \& van Leeuwen (1996; 2006) para analisar a representação dos refugiados nas fotografias que acompanham matérias online no Público durante a primeira metade de outubro de 2015. 0 estudo de 13 imagens mostra que há uma recorrente representação dos refugiados como grupos, e não indivíduos, nômades, em situação de risco e subordinação.

\author{
Palavras-chave: \\ jornalismo; discriminação; refugiados; Público; gramática visual
}

\begin{abstract}
According to the United Nations High Commissioner for Refugees, in 2015, nearly one million people from countries like Libya, Syria and Iraq, and from some politically unstable African nations, have risked themselves crossing the Mediterranean sea to seek a better life as refugees in Europe. This population flow was one of the most commented subject in European media during the year. This article resorts to the categories of Kress and van Leeuwen's visual grammar (1996; 2006) in order to analyze the depiction of refugees in the photographs contained in Público's online news during the first half of October 2015. The analysis of 13 images shows there is a recurrent representation of refugees as groups, not individuals, nomads, in high risk and subordination situations.
\end{abstract}

KEYWORDS:

journalism; discrimination; refugees; Público; visual grammar 


\section{INTRODUÇÃO}

Em 2015, a Europa recebe uma das maiores ondas migratórias dos últimos tempos, com pessoas deixando regiões conflituosas como Líbia, Síria, Iraque, e países africanos politicamente instáveis, buscando chegar ao Velho Continente, sobretudo através de barcos lançados ao Mar Mediterrâneo. A fuga em massa em busca de refúgio pelo mar fez, inclusive, ressurgir o termo "boat people", usado para se referir ao deslocamento maciço de pessoas do Vietnã, Laos e Camboja entre as décadas de 1970 e 1990, fugindo das consequências de tantos anos de guerra (ACNUR, 2000).

Contudo, a migração em massa registrada no primeiro semestre de 2015 foi a maior desde a Segunda Guerra Mundial, e veio acompanhada de um grande número de mortes, já que a travessia do oceano ocorre em condições clandestinas e precárias. Dados do Alto Comissariado das Nações Unidas para os Refugiados' ${ }^{1}$ (UNHCR, 2015), registraram 955.281 mil chegadas e 3625 mortes. Para Buriham (2015), este fluxo foi um dos temas mais debatidos pelos media da União Europeia no último ano.

Desde la perspectiva del tratamiento periodístico, son necesarias múltiples reflexiones. Los propios vocablos para denominar a estas personas, "refugiados" 0 "migrantes económicos", suponen diferentes puntos de vista, al intentar diferenciarles según las motivaciones que llevan al individuo a salir del país donde nació y/o reside (Buriham, 2015).

Neste trabalho opta-se pela utilização do termo "refugiado". Entende-se que a definição do conceito, cunhada em documentos normativos da Convenção de Genebra de 1951, é apropriada: "toda pessoa que se encontra fora de seu país de origem e que não pode regressar a ele como consequência de um medo fundado da perseguição por motivos de raça, religião ou nacionalidade, por suas opiniões políticas ou por pertencer a um grupo social".

Retomando a relevância dos media na questão, Silveirinha e Cristo (2004) destacam que a percepção pública dessas pessoas depende de um conjunto de fatores que vão das práticas do Estado à intervenção institucional, e um dos lugares privilegiados de construção da imagem são os meios, "locus de uma cultura pública entendida como conjunto de símbolos, valores, visões do mundo e formas comunicacionais comuns a pessoas e grupos que interagem num espaço público" (Silveirinha e Cristo, 2004: 118). E são tantos os media que os efeitos que produzem não são homogêneos, afinal, apresentam diferentes linhas editoriais, agendas, e outros fatores que fazem variar o discurso jornalístico.

0 objetivo do artigo é analisar como refugiados são representados visualmente em matérias online do jornal Público. As peças selecionadas foram publicadas na primeira metade (dias 1 a 15) de outubro de 2015, mês selecionado devido ao grande número de matérias relacionadas ao tema, com considerável variação de abordagens e imagens. Serão analisadas, portanto, as fotografias usadas para ilustrar as matérias, a partir da gramática visual proposta por Kress e van Leeuwen $(1996,2006)$.

0 artigo parte de um quadro teórico onde são feitas reflexões acerca dos refugiados na sociedade contemporânea e da visibilidade dessas pessoas nos media.

1 Original em inglês "United Nations High Commissioner for Refugees" (UNHCR) 
Buscar-se-á compreender o porquê da temática ser tema de material jornalístico e também de trabalhos acadêmicos da área da Comunicação. Em seguida é apresentada a metodologia utilizada para a análise das imagens, desde o processo de seleção do material até às classificações que compõem a gramática visual aplicada. Então há espaço para a apresentação dos resultados encontrados, seguido pelo tópico final, a conclusão, onde se busca identificar padrões e singularidades nos casos estudados.

\section{QUADRO TEÓRICO}

Vivemos no que McLuhan (1968) denomina uma aldeia global, onde estamos permanentemente conectados e, por isso, também mais expostos. A evolução das tecnologias da informação, desde o telégrafo aos meios eletrônicos e ao computador, anuncia a emergência de uma nova partilha sensorial a uma escala total ou aldeia global, estado final da comunhão universal da humanidade. A multiplicação das redes de comunicação nos fornece informações sobre "os outros", sendo, muitas vezes, a única fonte de conteúdo a que temos acesso sobre os que nos são distantes ou desconhecidos.

A polarização entre "nós" e "eles", adverte Barbosa (2012), "traduz discursivamente uma realidade sociológica que os media diariamente, encenam" (2012: 231). A opinião que temos sobre quem nos é estranho e suas crenças, valores, costumes e tradições derivam das mensagens mediáticas, construídas, muitas vezes, sem ouvi-los.

0 seu poder de condicionamento do nosso comportamento e do nosso imaginário é enorme. Hoje, são os media que concretizam e moldam, em grande medida, a nossa perceção e a nossa aceitação ou rejeição da multiculturalidade e da interculturalidade. A sua influência é decisiva, como mostra a história dos tempos mais recentes, em termos de hospitalidade ou hostilidade em relação a estranhos culturais, sejam eles minorias étnicas, imigrantes, forasteiros ou refugiados. Devemos, pois, contar com os media na modelação de atitudes e condutas em relação aos outros culturalmente diferentes e, sobretudo, na construção de uma cidadania mais inclusiva do ponto de vista cultural (Barbosa, 2012: 232).

Essa dinâmica contemporânea trouxe também novas problemáticas às questões interculturais. A quantidade de informações a respeito do "outro" em circulação cria uma sensação de familiaridade, mas que pode se revelar simples e redutora. Augé (1997) acredita ser justamente este o paradoxo atual:

A categoria do Outro recompõe-se pelo fato de que, se esses fenômenos [a dinâmica contemporânea] tendem a reduzi-la ou apagá-la, algumas das reações que provocam (xenofobia, racismo, crise de identidade) tendem, ao contrário, não apenas a cristalizá-la, mas a torná-la impensável, não simbolizável (Augé, 1997: 144).

González Cortés (2006) destaca que a maioria das pessoas não tem contato direto com imigrantes ou refugiados, mas isto "não cria obstáculo algum a que opinem sobre as suas características pessoais, as diferentes culturas de que são originários e sobre os valores, direitos e costumes que Ihes são próprios" (2006: 54). Desta forma, o que acaba por ocorrer é a incorporação de representações e modelos mentais produzidos 
não pelo indivíduo, mas a ele repassados através dos media. Estes, por sua vez, não são imparciais ou inocentes, mas construídos para determinadas finalidades.

Barbosa (2012) define os meios de comunicação como oficinas de representações positivas e negativas: há sempre uma intenção subjacente que comanda as mensagens e as iconografias difundidas. Tal intenção, no caso do tratamento noticioso das minorias, "pode ir em sentido contrário à promoção da tolerância, do respeito mútuo, do diálogo, do reconhecimento e do entendimento" (2012: 235).

Silveirinha e Cristo reconhecem uma grande atenção dos Estudos da Comunicação nas ligações entre imigração e racismo nos media, ancorados "na tendência para os media refletirem e reforçarem a distribuição de poder social e político" (2004: 120). As autoras reforçam que as relações entre media e imigração não são unívocas, já que os media retiram sua substância comunicacional de fatores estratégicos como captação de audiências, e também da sua constituição como agentes do espaço público (meios de reprodução simbólica da comunicação).

Neste processo, que é também de "agendamento", são construídas identidades e lugares de desvio e normalidade. Quando os imigrantes são estigmatizados como "problemáticos", mas também quando são relatadas as suas parcas histórias de "sucesso", constroem-se socialmente as suas identidades e também a do Estado nacional que os recebe (Silveirinha e Cristo, 2004: 121).

Silvestre (2011) resume a atenção à problemática dos refugiados no âmbito internacional, que se inicia após a Primeira Grande Guerra, "nomeadamente através da criação da Sociedade das Nações, em 1920 (2011: 3). Contudo, a conjuntura político-econômica da época e a ausência de referência explícita aos direitos humanos e a uma definição de "refugiado" no estatuto da organização limitaram 0 campo de alcance da Sociedade. Foi somente durante a Segunda Guerra Mundial, em novembro de 1943, que se deu a criação da Administração das Nações Unidas para o Auxílio e Restabelecimento (ANUAR), pelos países Aliados. 0 objetivo era prestar assistência às pessoas deslocadas em áreas sob o controlo dos Aliados e apoiar na reabilitação das zonas devastadas.

Preocupado com as tensões na constituição das imagens do "outro", Canclini (1998) questiona se essa intensa rede informacional "complexifica e torna mais sutil a compreensão dos outros ou leva a repetir esquemas binários, maniqueístas, que dividem o mundo entre dominantes e dominados, modernos e tradicionais, centros e periferias?' (Canclini, 1998: 7). Já Mattelart (1999) formula o conceito de 'comunicação-mundo': "Os Estados e as relações interestatais não são mais o único pivô de ordenamento do mundo. As grandes redes de informação e comunicação, com seus fluxos 'invisíveis', 'imateriais', formam 'territórios abstratos', que escapam às antigas territorialidades" (Mattelart, 1999: 166).

A partir da problematização exposta sobre a polarização entre "nós" e "eles", e 0 importante papel desempenhado pelos meios de comunicação em refletirem e reforçarem a distribuição de poder social e político, faz-se relevante a análise cujo objetivo é analisar como os refugiados que buscaram alcançar a Europa através do Mar Mediterrâneo, em 2015, são representados visualmente em matérias online do jornal Público. 


\section{Metodologia}

Inicialmente foram considerados para análise das fotografias de matérias online os jornais portugueses de maior circulação. Escolheu-se o Público² pela facilidade de busca no site do jornal, que permite a visualização da lista de matérias publicadas em qualquer período, o que em outros portais mostrou-se limitado ou inacessível. 0 processo de seleção das matérias foi feito de forma manual na secção Mundo do site do Público durante o mês de outubro (01 a 31) de 2015. Diante da grande quantidade de matérias encontradas (37), limitou-se 0 trabalho às duas primeiras semanas do mês (dias 1 a 15) para se ter um trabalho de tamanho compatível com o proposto. Foram, então, elencadas 17 matérias relacionadas à crise de refugiados na Europa (Tabela 1), pré-selecionadas para a análise inicial, independente de conterem fotografia.

Em seguida, apenas as 16 que contêm fotos seguiram como alvo da análise. Daí, optou-se por excluir aquelas que não representavam refugiados, mas sim figuras políticas ou outras situações. Assim, outras três imagens (matérias 5, 6 e 7 da Tabela 1) deixam de fazer parte da análise, que centra-se nas 13 fotografias que retratam os refugiados.

Tabela 1. Matérias sobre refugiados publicadas no Público online no período de análise

\begin{tabular}{|c|c|c|c|}
\hline Matéria & Título & Data & Fotografia \\
\hline 1 & $\begin{array}{l}\text { Podem chegar à Europa } \\
1,4 \text { milhões de refugiados } \\
\text { entre } 2015 \text { e 2016, diz ONU }\end{array}$ & $01 / 10$ & Sim (Figura 1) \\
\hline 2 & $\begin{array}{l}\text { Merkel volta a pedir união } \\
\text { à Europa para lidar com } \\
\text { os refugiados }\end{array}$ & $03 / 10$ & Não \\
\hline 3 & $\begin{array}{l}\text { Mais de uma centena de } \\
\text { migrantes força intrusão } \\
\text { no túnel da Mancha }\end{array}$ & $03 / 10$ & Sim (Figura 2) \\
\hline 4 & $\begin{array}{l}\text { Cerca de } 630 \text { mil } \\
\text { migrantes entraram } \\
\text { ilegalmente na Europa } \\
\text { desde Janeiro }\end{array}$ & $04 / 10$ & Sim (Figura 3) \\
\hline 5 & $\begin{array}{l}\text { Para ajudar UE com os } \\
\text { refugiados, Erdogan quer } \\
\text { apoio contra terroristas }\end{array}$ & $05 / 10$ & $\operatorname{Sim}^{*}$ \\
\hline 6 & $\begin{array}{l}\text { Alemanha prevê entrada } \\
\text { de } 1,5 \text { milhões de refugia- } \\
\text { dos até o final do ano }\end{array}$ & $05 / 10$ & $\operatorname{Sim}^{*}$ \\
\hline 7 & $\begin{array}{l}\text { Chanceler austríaco foi a } \\
\text { Lesbos ver o que é uma } \\
\text { "porta de entrada" na UE }\end{array}$ & $06 / 10$ & $\operatorname{Sim}^{*}$ \\
\hline 8 & $\begin{array}{l}\text { UE paga a Erdogan para } \\
\text { tentar travar os "milhões } \\
\text { de refugiados da Síria" }\end{array}$ & $06 / 10$ & Sim (Figura 4) \\
\hline
\end{tabular}

2 http://www.publico.pt 


\begin{tabular}{|c|c|c|c|}
\hline 9 & $\begin{array}{l}\text { Para compensar o envel- } \\
\text { hecimento, países ricos } \\
\text { devem abrir portas aos } \\
\text { imigrantes }\end{array}$ & $07 / 10$ & Sim (Figura 5) \\
\hline 10 & \begin{tabular}{|l|} 
União Europeia reforça \\
medidas de repatriamento \\
de imigrantes económicos \\
\end{tabular} & $08 / 10$ & Sim (Figura 6) \\
\hline 11 & \begin{tabular}{|l|} 
Crise migratória na mira \\
do Nobel da Paz, mas \\
ainda se aceitam apostas
\end{tabular} & $08 / 10$ & Sim (Figura 7) \\
\hline 12 & $\begin{array}{l}\text { Partilha de refugiados } \\
\text { na UE começa com } 19 \\
\text { eritreus a caminho da } \\
\text { Suécia }\end{array}$ & 09/10 & Sim (Figura 8) \\
\hline 13 & \begin{tabular}{|l|} 
Bebé de um ano encon- \\
trado morto num barco de \\
refugiados em Lesbos
\end{tabular} & $09 / 10$ & Sim (Figura 9) \\
\hline 14 & $\begin{array}{l}\text { Alemanha e UE querem } \\
\text { novo imposto para finan- } \\
\text { ciar apoio aos refugiados }\end{array}$ & $10 / 10$ & Sim (Figura 10) \\
\hline 15 & $\begin{array}{l}\text { Grécia rejeita cooperação } \\
\text { militar com Turquia no } \\
\text { Mar Egeu para travar } \\
\text { refugiados }\end{array}$ & $14 / 10$ & Sim (Figura 11) \\
\hline 16 & $\begin{array}{l}\text { UE vai anunciar mais } \\
\text { medidas "externas" } \\
\text { para travar a crise de } \\
\text { refugiados }\end{array}$ & $15 / 10$ & Sim (Figura 12) \\
\hline 17 & $\begin{array}{l}\text { Turquia regateia acordo } \\
\text { com Europa para travar } \\
\text { fluxo de refugiados }\end{array}$ & $15 / 10$ & Sim (Figura 13) \\
\hline
\end{tabular}

As matérias destacadas com * indicam que não tinham fotografias que interessavam a esta análise, por não representar refugiados.

A gramática visual de Kress e van Leeuwen (1996; 2006) propõe um olhar ampliado sobre a noção de texto, diante da grande quantidade de imagens que circulam atualmente, e coloca a linguagem visual em destaque, por isso foi o método selecionado para guiar a análise das fotografias. Na comunicação contemporânea, os textos escritos dividem espaço com textos que apresentam várias modalidades semióticas em sua composição, oferecendo diferentes leituras de mundo. Kress, portanto, amplia a noção de texto:

Um texto pode ser formado por vários modos semióticos (palavras e imagens por exemplo) e portanto, podemos chegar à noção de multimodalidade. Com o advento de materiais computadorizados, multimídia e interacional, esta forma de conceituar a semiose se torna cada vez mais pertinente (Kress, 1995: 7).

Kress \& van Leeuwen (1996; 2006) organizaram uma proposta teórico-metodológica para a análise crítica de textos multimodais, na qual uma imagem deve 
ser analisada por três funções, que atuam simultaneamente em seu processo de produção de sentido:

- função representacional: maneiras de se representar o que está na imagem, seja uma coisa ou uma pessoa. Subdividem-se entre significados narrativos e conceituais, sendo aqueles relacionados a ações e estes ancorados na essência do que é retratado;

- função interacional: relações estabelecidas entre os participantes representados, os produtores da imagem e os espectadores, através de elementos como enquadramento, cor, luz e perspectiva;

- função composicional: forma pela qual os recursos anteriores se integram para estruturar e dar coerência à significação

Os detalhes sobre cada função serão revelados no item a seguir, no decorrer das análises das 13 fotografias selecionadas na secção Mundo do site do jornal Público. As legendas das imagens, incluindo crédito de foto, foram mantidas como estão no portal.

\section{Apresentação dos resultados}

Figura 1. Refugiados na fronteira da Grécia com a Macedónia, em Gevgelija. Por:Armend Nimani/AFP. Recuperado de publico.pt

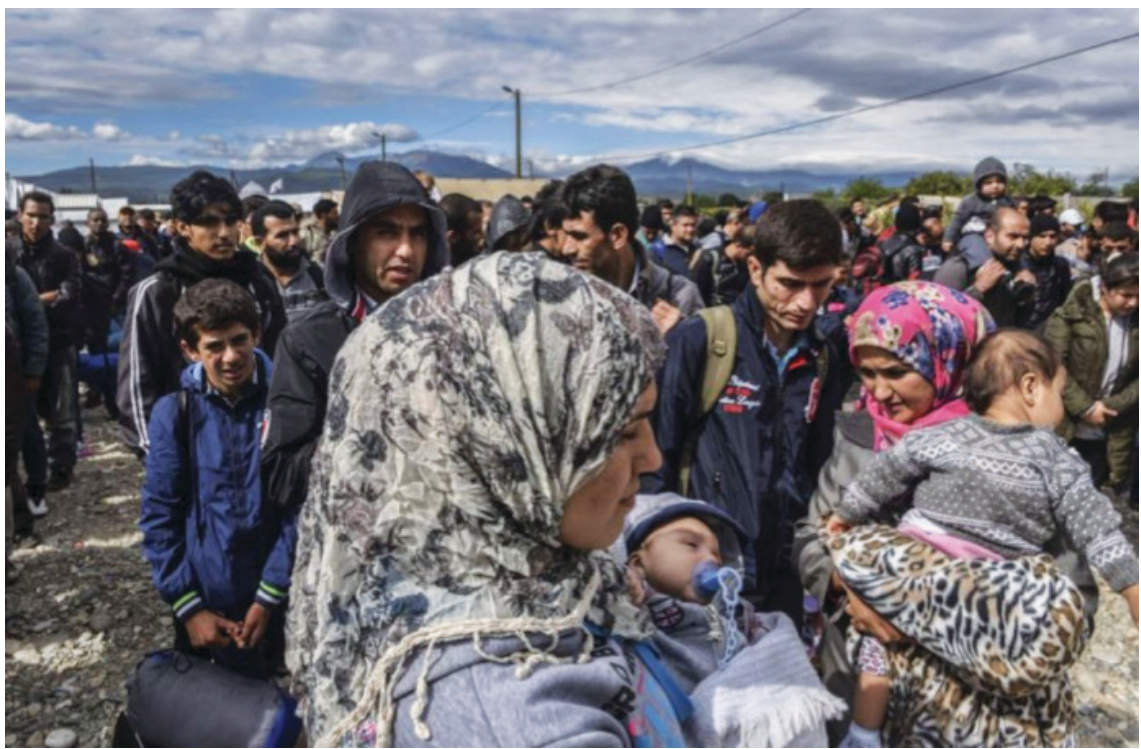

A Figura 1 estrutura-se sobre um grupo de sete pessoas representado em primeiro plano. Contudo, do ponto de vista representacional, analisa-se a foto pelo viés narrativo e tem-se que duas dessas pessoas são os atores da foto, por serem os participantes mais proeminentes em relação aos demais: as duas mulheres. 
Estas estão destacadas por fatores como proximidade (ao produtor da imagem), foco e cor (suas vestes coloridas se destacam diante da monocromia de tons de azul escuro e preto da foto). Ambas levam nos braços crianças de colo, evocando ainda mais a fragilidade dos refugiados e necessidade de proteção. Do ponto de vista conceitual, que analisa os participantes em termos de essência, podemos interpretar a relação criança - mãe (lembrando que esta é o ator) como subordinado - subordinador.

Avançando ao ponto de vista interacional, que trata da relação entre o representado, o produtor da imagem e o espectador, o que interessa não são as mulheres atores da foto, mas o indivíduo logo atrás, que surge como o único a apresentar marca mínima de contato com o produtor e espectador, por olhar diretamente à câmera, de modo frontal. Os demais representados, incluindo os atores, têm olhares para baixo ou outras direções que não permitem contato ou qualquer identificação. Por fim, a composição da imagem corrobora o destaque aos atores representados, já que aparecem em planos médios, cores vistosas, em primeiro plano e altamente focados, em contraste com os demais retratados; a moldura da foto guia 0 olhar aos atores.

Figura 2. Os migrantes foram todos recolhidos pelas autoridades ao longo da noite.

Por: Pascal Rossignol/Reuters. Recuperado de publico.pt

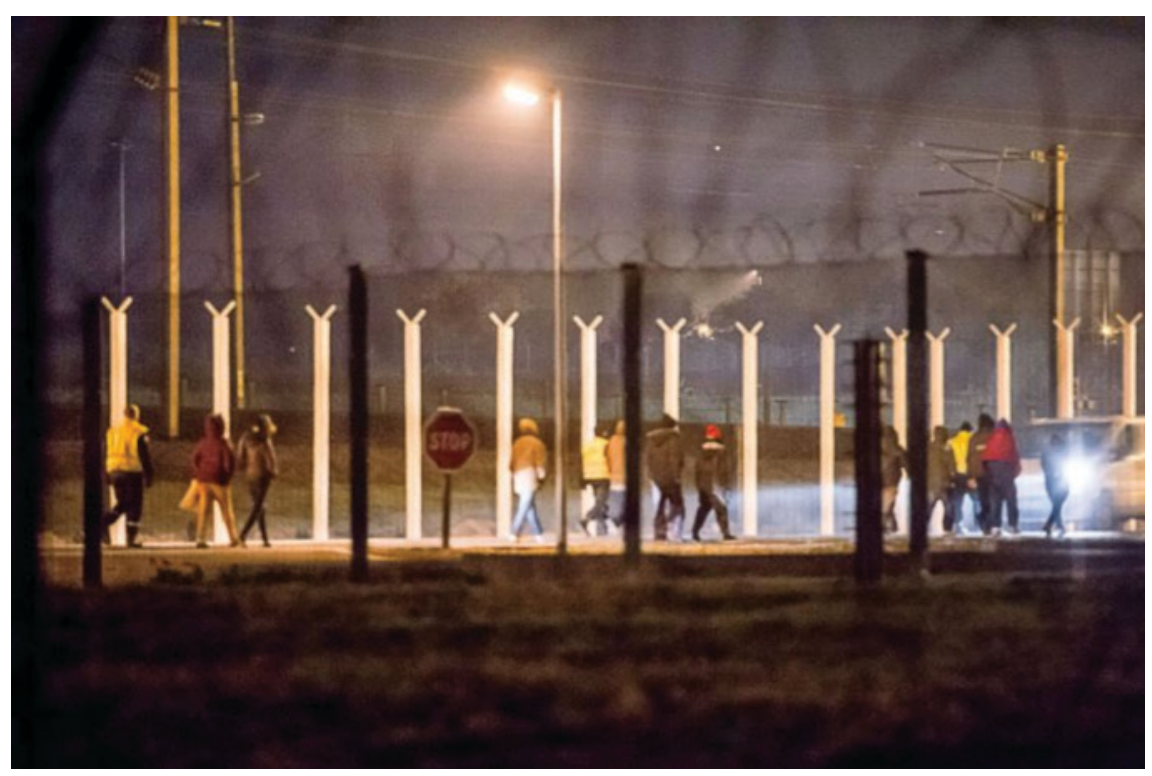

A Figura 2 não apresenta ator, mas um grupo de pessoas que, em conjunto, atuam como vetores da imagem, segundo a ótica narrativa da função representacional. Todos estão representados de forma semelhante: plano aberto, distante, em mesma linha horizontal, de forma que não sejam possíveis quaisquer distinções entre eles, já que estão cobertos por casacos e chapéus e retratados de costas. Tais estratégias composicionais atuam ainda com fatores composicionais: um ambiente escuro e inóspito, com poucas luzes, cercas e arames farpados. 
No entanto, acredita-se no poder vetorial do grupo pois todos caminham para o lado direito da foto, e é para lá que o olhar do espectador é guiado. Do ponto de vista interacional, é este movimento a ser considerado como relação entre representados e espectador, tamanha a sutileza com que os refugiados surgem na imagem. Em função da distância e ângulo de captura, o produtor da imagem não aparenta qualquer relação possível com os retratados.

Figura 3. A imigração disparou em 2015. Por: Robert Atanasovski/AFP. Recuperado de publico.pt

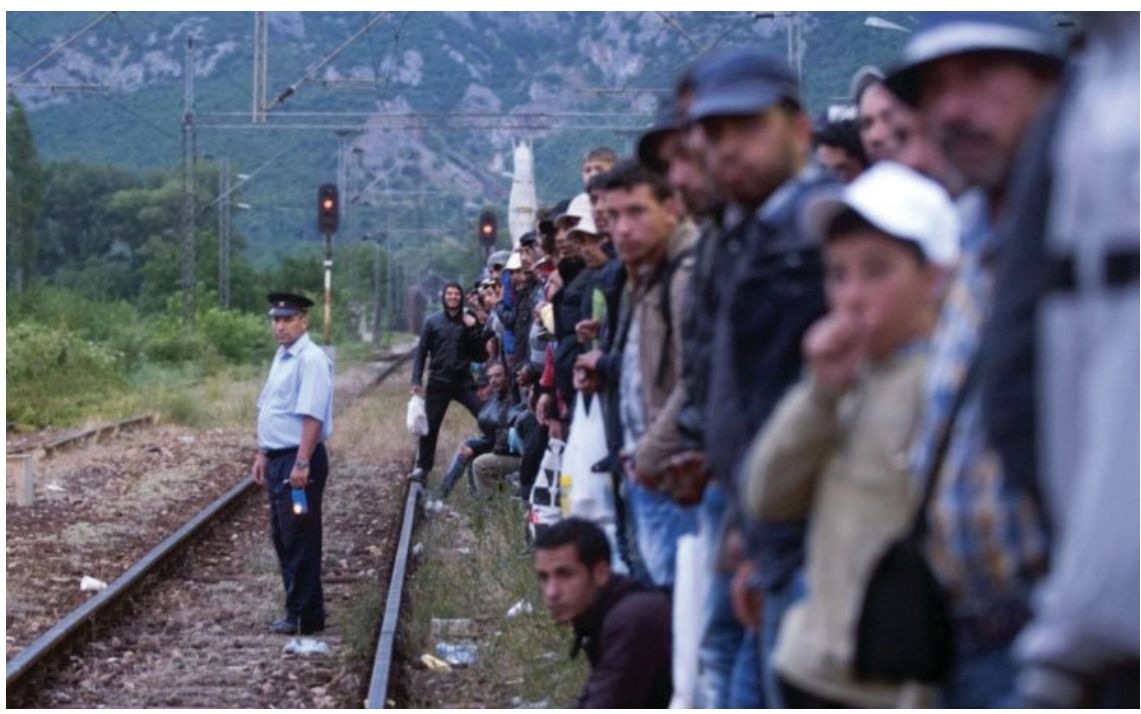

A Figura 3 é intrigante pois retrata muitos refugiados e apenas um policial, mas é justamente este último o participante de quem parte o vetor da imagem. É nele que está o foco da câmera e, composicionalmente, aparece deslocado dos demais retratados, à esquerda, onde Kress \& van Leeuwen (1996; 2006) afirmam ser 0 espaço para os elementos corriqueiros, denominados "dados". 0 lado direito, em oposição, é o espaço para o "novo", o elemento surpresa, no caso 0 grande grupo de refugiados em conjunto. Assim se estabelece o que os autores definem como valor informativo, que dá diferentes "valores" a cada aspecto retratado conforme a área onde está posicionado.

Do ponto de vista representacional, apesar de os refugiados estarem destacados pelo fator proximidade (ao produtor da imagem), os aspectos foco e cor guiam 0 olhar ao policial. A monocromia e falta de foco sobre o grupo os reúne como uma massa, sem permitir individualizações, o oposto do que ocorre sobre o oficial da lei.

Como na figura anterior, em que o movimento nos leva a olhar para um dos lados, neste caso é o olhar dos retratados (todos para o mesmo ponto) que nos leva a refletir sobre o comboio que está por vir - pensamento este influenciado pelo trilho que corta a imagem longitudinalmente. Remete-se também a ideia de espera e de esperança, na medida em que o espectador não sabe se algo de fato vem sobre os trilhos. 
Figura 4. Imigrantes a dormir junto a um graffiti no porto de Mytilene, na ilha grega de Lesbos.

Por: Aris Messinis/AFP. Recuperado de publico.pt

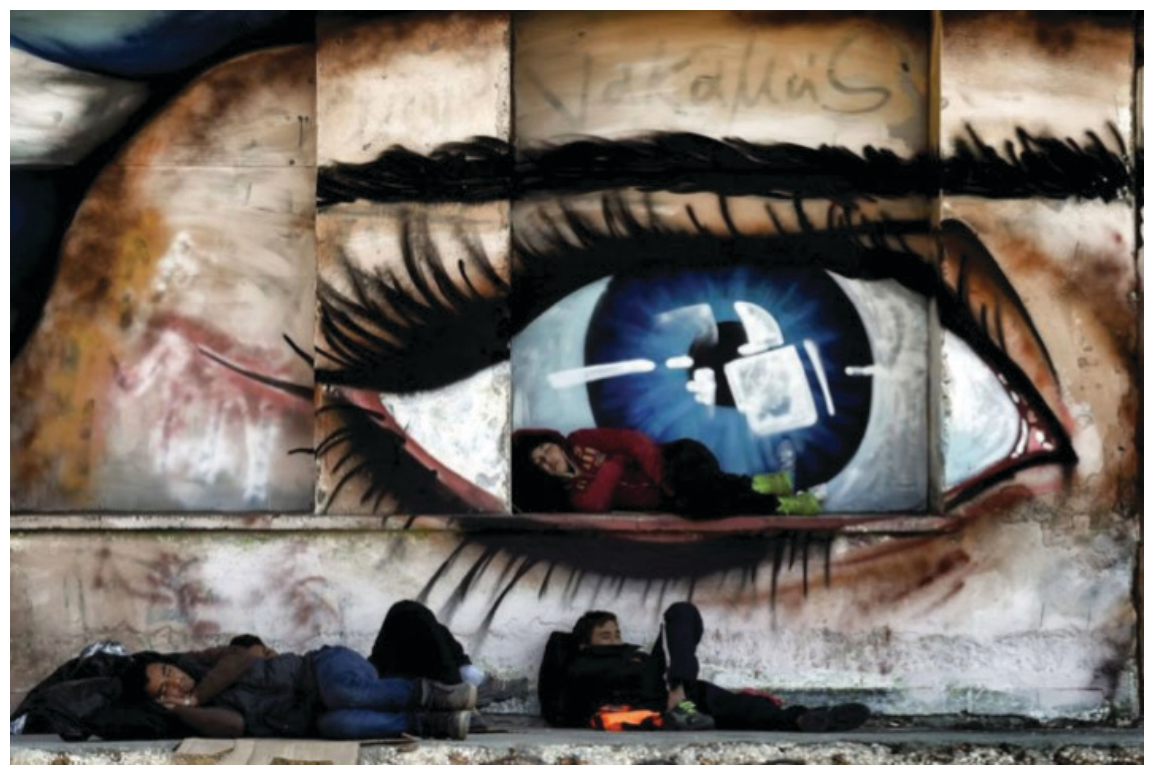

A Figura 4 retrata quatro refugiados a dormir na rua e atrás deles um graffiti que mostra um olho humano. Por seu tamanho, cor, foco e posição central na imagem, nota-se que é o olho humano que atua como subordinador, sobre os refugiados subordinados. Interacionalmente, o espectador e o produtor da imagem têm relação direta com o olho (olhar frontal, direto), mas não com os refugiados.

Isso é compreensível, pois no processo classificacional, que é parte da função conceitual da imagem, identifica-se a situação como sem vetores, mas apenas com a relação de subordinação relatada. Os refugiados retratados não têm rostos visíveis, estando cobertos total ou parcialmente por casacos ou pelos colegas.

Todos estão na metade inferior do quadro, deslocados para o centro esquerda. Novamente evoca-se a noção de Kress \& van Leeuwen (1996; 2006) sobre a parte esquerda da imagem, que é o espaço para os elementos corriqueiros, em oposição ao direito, que seria o espaço para o "novo". Refugiados em grupos, em situação de vulnerabilidade na rua está retratado como elemento "dado" e o olho aparece à direita, como surpresa. 
Figura 5. Refugiados encaminham-se para um comboio na Croácia.

Por: Dado Ruvic/Reuters. Recuperado de publico.pt

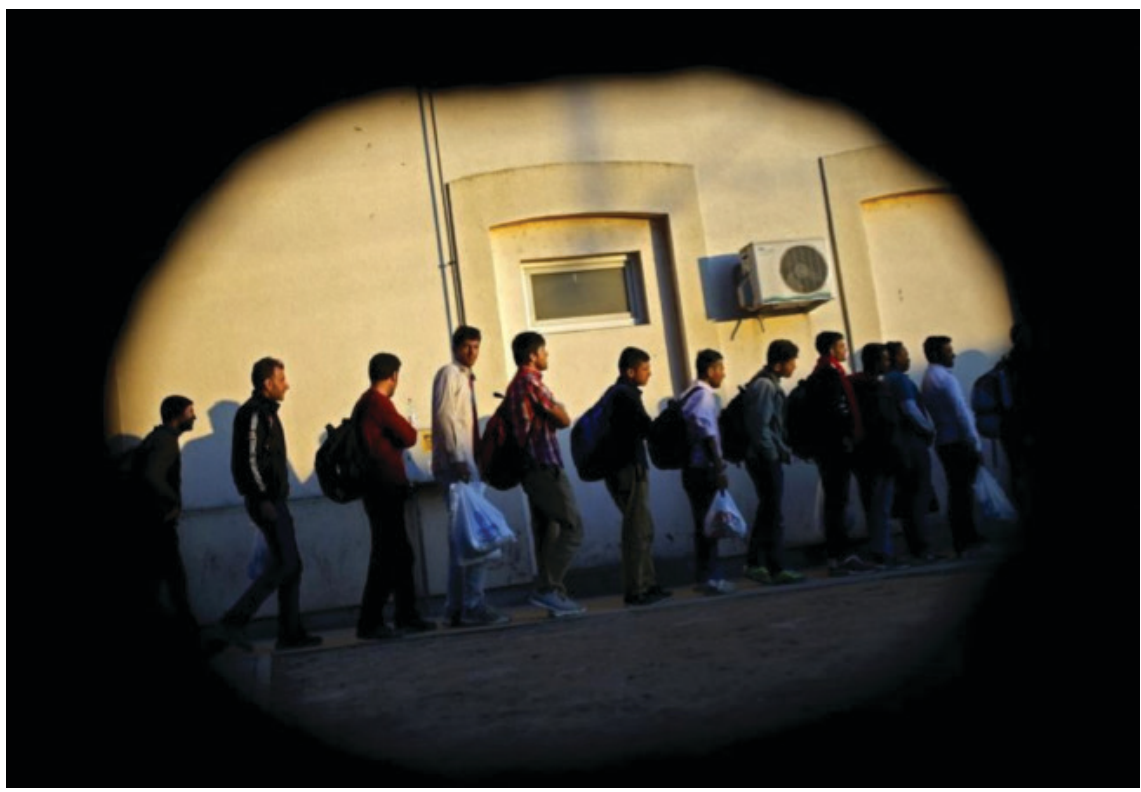

A Figura 5 tem como item composicional mais marcante a presença de uma moldura preta arredondada, como se o produtor da imagem e o espectador estivessem a espiar a situação retratada. Novamente tem-se um caso onde um grupo de refugiados segue em uma mesma direção, direcionando o olhar do espectador para a direita, e mais uma vez o espectador é incapaz de prever para onde vão, ou o que existe à direita da imagem, na parte não retratada.

A cena pode ser definida como uma fila de refugiados, todos de lado indo em direção à direita. Todos têm roupas e objetos como mochilas e sacos parecidos, assim como um mesmo posicionamento do corpo, curvado para a frente em sinal de cansaço, embora não seja possível inferir se estão a caminhar ou parados.

Interacionalmente deve-se destacar um ponto de contato em um dos participantes representados, o senhor mais alto da foto, que olha diretamente ao produtor $\mathrm{e}$ ao espectador, classificando a imagem em questão, segundo Kress \& van Leeuwen (1996; 2006), como uma imagem de demanda. 
Figura 6. A UE quer dar um sinal de firmeza para travar a imigração ilegal.

Por: Ismail Zitouny/Reuters. Recuperado de publico.pt

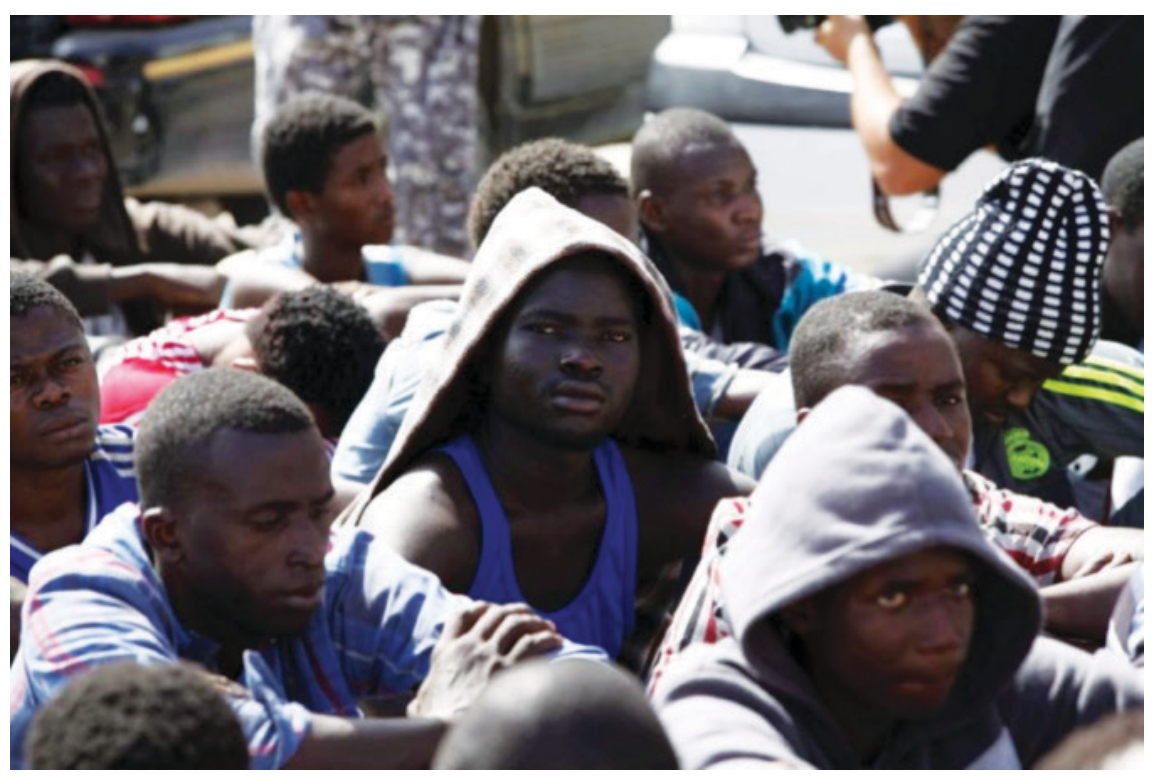

A Figura 6 é diferente das demais no quesito representacional, já que destaca um único ator, centralizado. Ele é o próprio vetor da imagem, pois prende o olhar do espectador e para ele olha diretamente. Como na análise anterior, cria-se, na função interacional, uma imagem demanda. Embora os demais retratados estejam fora do foco principal, notam-se expressões e olhares, fato também distintivo desta foto diante das previamente analisadas.

0 homem retratado no centro da imagem é também proeminente pelo aspecto foco e tamanho, sendo, portanto, o elemento "saliente", segundo a gramática visual. Seu entorno, embora seja composto por diversas pessoas, é monocromático e pouco focado, o que não atrai o olhar do espectador. Ainda assim, nota-se que, em geral, os retratados olham para a frente, como se ouvissem ou observassem algo ou alguém. Como ocorreu em outros casos analisados previamente, não é possível para o espectador prever o que seria tal elemento ou pessoa que prende a atenção das pessoas na imagem. 
Figura 7. Desde o início do ano mais de 630 mil pessoas tentaram chegar à Europa.

Por: Yannis Behrakis/Reuters. Recuperado de publico.pt

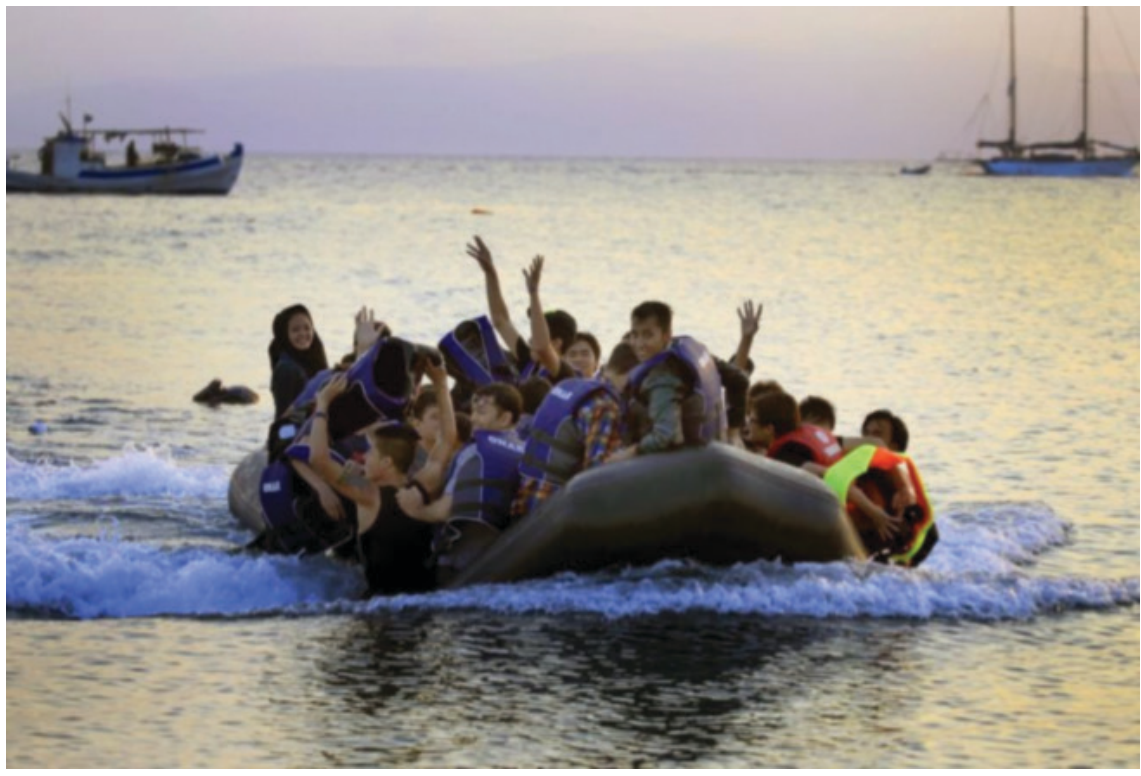

Na Figura 7 está retratado um barco de refugiados possivelmente a se aproximar da costa, já que algumas pessoas estão a saltar para a água. Nota-se euforia através desse movimento e também de outras pessoas que levantam os braços a abanar. No entanto, quase não se veem rostos e expressões, com exceção de dois ocupantes. São eles que, representacionalmente, são os atores da foto e, interacionalmente, estabelecem relação com o espectador ao olhá-lo de forma direta e frontal.

Este olhar frontal remete à ideia de que o produtor da imagem encontra-se em terra firme, para onde o barco vai. Ao mesmo tempo, ao se observar o conjunto de pessoas de forma mais ampla, vê-se que há algumas a olharem e acenarem para 0 lado esquerdo do quadro, o que confunde o espectador: por que algumas olham para a frente e outras para a esquerda?

Mesmo diante de tal divisão, os refugiados nesta foto são claramente representados como um grupo, uma massa, definidos pelo tom monocromático em azul da imagem, que quase os confunde entre si e com o oceano. Do ponto de vista conceitual, no entanto, pode-se interpretar um dos atores principais, o homem à frente do barco, como subordinador dos demais, por estar em posição de destaque e a estabelecer relação direta com o espectador e com o produtor da imagem. 
Figura 8. Um dos 19 refugiados que partiram de Itália para a Suécia.

Por: Andreas Solaro/AFP. Recuperado de publico.pt

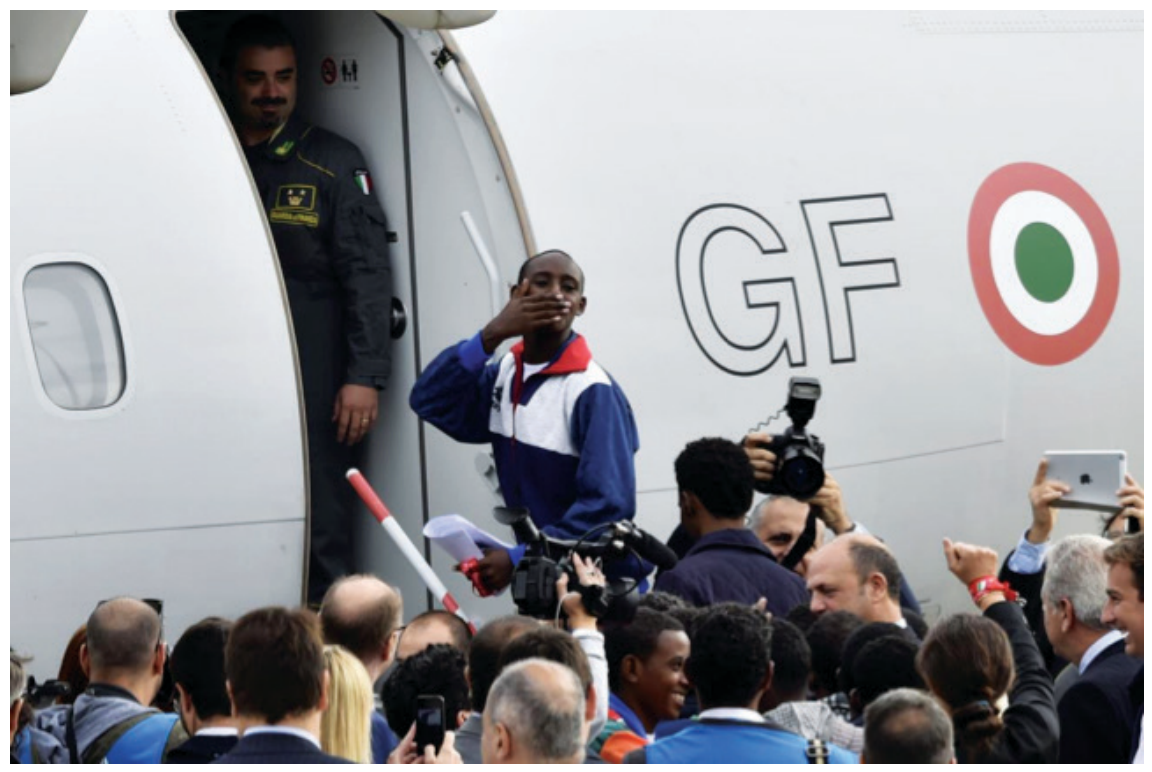

A Figura 8 é diferente das anteriores, por retratar apenas um refugiado - embora seja possível inferir que a pessoa de costas logo atrás dele também seja, não há destaque sobre ela. Ele é o vetor e ator da foto, ocupando posição de destaque, no centro da foto, bem focado, com roupas coloridas que o diferenciam do resto da massa humana que ocupa a posição inferior do quadro.

É distintivo também o facto de o retratado parecer feliz, a mandar beijos para quem 0 assiste. 0 oficial que 0 aguarda na aeronave a ele direciona um olhar $\mathrm{e}$ semblante igualmente felizes. Esta, portanto, é uma fotografia que representa um momento feliz, diante de todas as outras a retratar instantes distintos. No âmbito das funções narrativas, tem-se um caso de estrutura não-transacional, segundo Kress \& van Leeuwen, onde a ação não é dirigida a nenhum outro participante, por ter-se apenas um ator. 
Figura 9. Migrantes e refugiados chegam à ilha grega de Lesbos.

Por: Aris Messinis/AFP. Recuperado de publico.pt

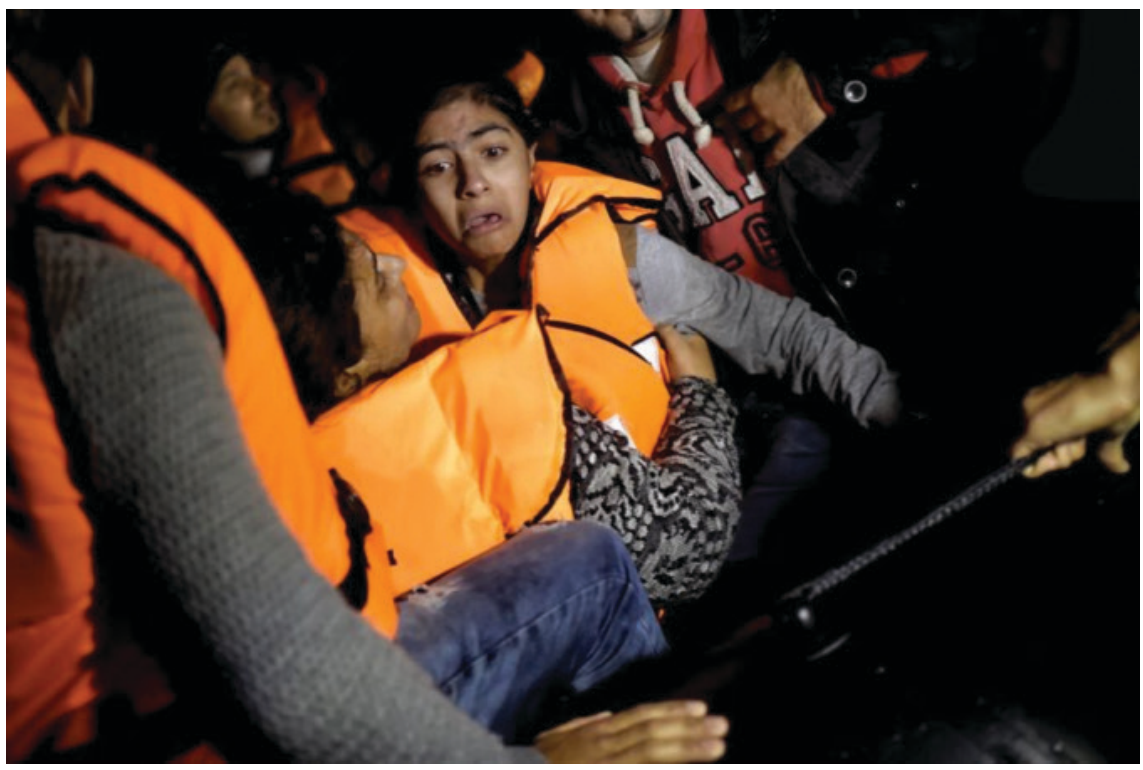

Na Figura 9 novamente há um único rosto, chamando atenção total para si, mas sabe-se que existem muitos outros refugiados ao redor da participante principal, que atua como ator na imagem. Os demais retratados estão, em geral, com rostos fora do enquadramento, tornando o contexto mais genérico, e destacando ainda mais 0 ator principal. Os tons escuros do entorno fazem com que 0 olhar do espectador seja preso ao centro da imagem, com 0 autor, e as cores vivas em tons de laranja.

Apesar de atuar representacionalmente como ator principal, e representar sozinha todo 0 sentimento de angústia transmitido pela imagem, a menina centralizada aparece ao colo da mãe, evocando, como visto na Figura 1, uma relação de subordinação. 
Figura 10. Grupo de refugiados que chegou na sexta-feira à ilha grega de Lesbos.

Por: Dimitar Dilkoff/AFP. Recuperado de publico.pt

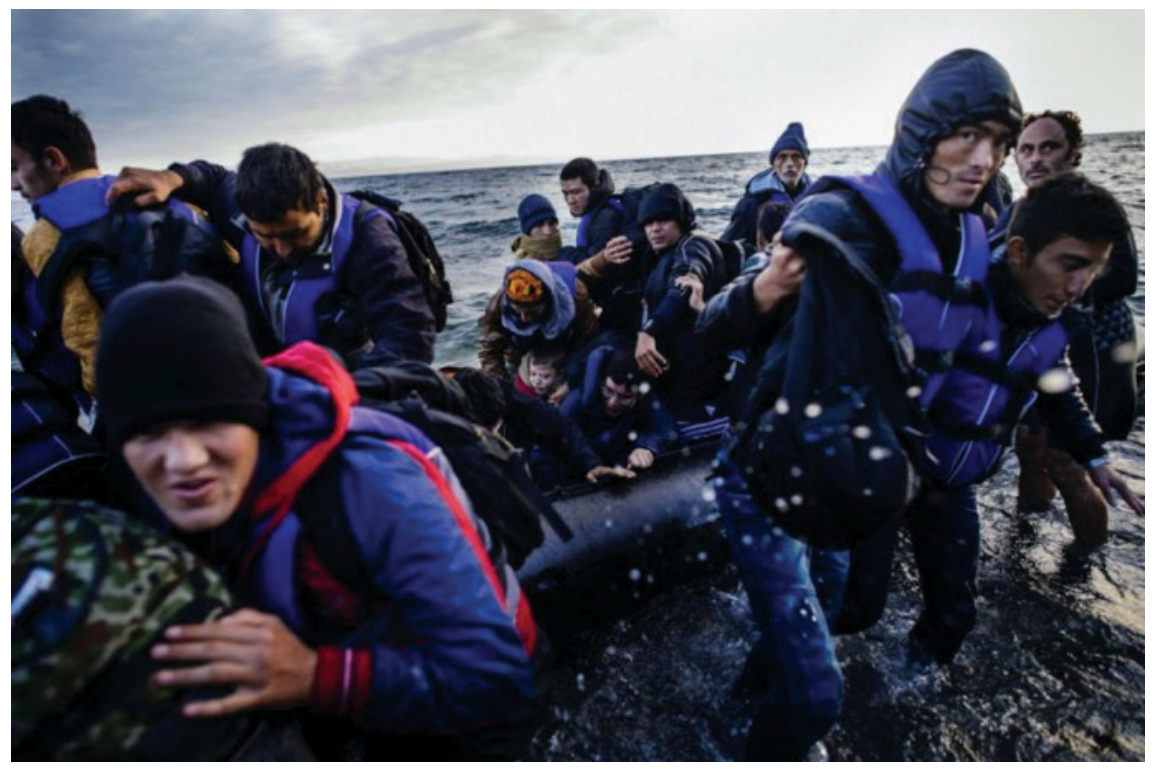

De maneira semelhante à Figura 7, a Figura 10 tem um tom único de azul escuro, que marca a composição. São muitas pessoas a deixar o mar com trajes semeIhantes, que as unificam em um grande grupo. Aliado a isto, tem-se uma situação única em que dois atores se destacam no grupo.

É possível ver um rosto com clareza, embora fora de foco, mas que está em primeiro plano, deslocado ao lado direito da imagem (local do "novo"). Ele é 0 ponto interacional da análise, pois olha diretamente ao produtor da imagem e, consequentemente, ao espectador. Contudo, não é ele que passa a emoção da imagem, mas sim o homem ao lado esquerdo (local do "dado"), que mesmo sem ter o rosto visível, simboliza a confusão e tensão do momento, e está destacado pelos aspectos proximidade e cor, já que veste tons de vermelho chamativos diante da monocromia em azul. 
Figura 11. Barco da guarda costeira grega vigia um bote com refugiados que chega a Lesbos, no Mar Egeu. Por: Dimitar Dilkoff/AFP. Recuperado de publico.pt

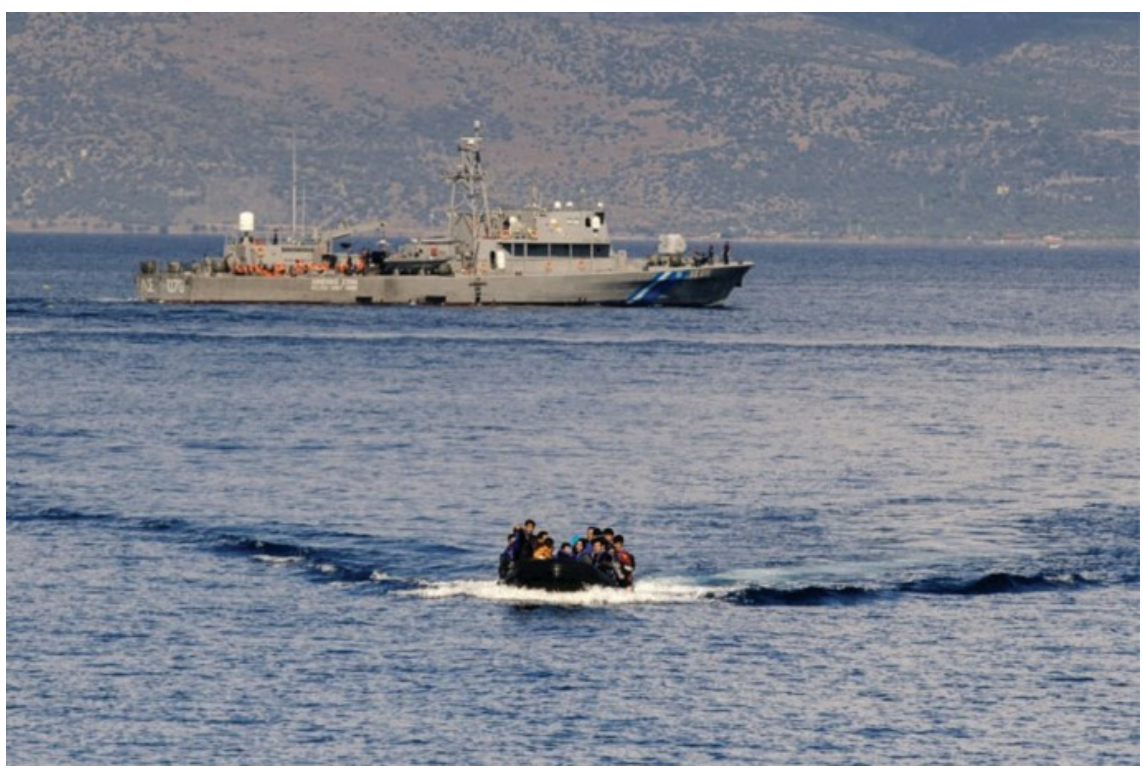

A Figura 11 não permite uma análise com relação a indivíduos, pois 0 barco de refugiados está em plano bastante aberto e afastado de maneira que não se vê quantas pessoas estão lá ou qualquer outro detalhe de personificação das mesmas. Encara-se, portanto, o barco como o objeto vetor da imagem, representado de maneira a mostrar sua fragilidade diante da grandeza de outro muito maior que está logo atrás, possivelmente da marinha, que faz a abordagem aos transportes ilegais. Nota-se, aí, novamente a ideia de subordinação do ponto de vista conceitual. 
Figura 12. Mais um barco que chegou à Grécia vindo da Turquia.

Por: Dimitar Dilkoff/AFP. Recuperado de publico.pt

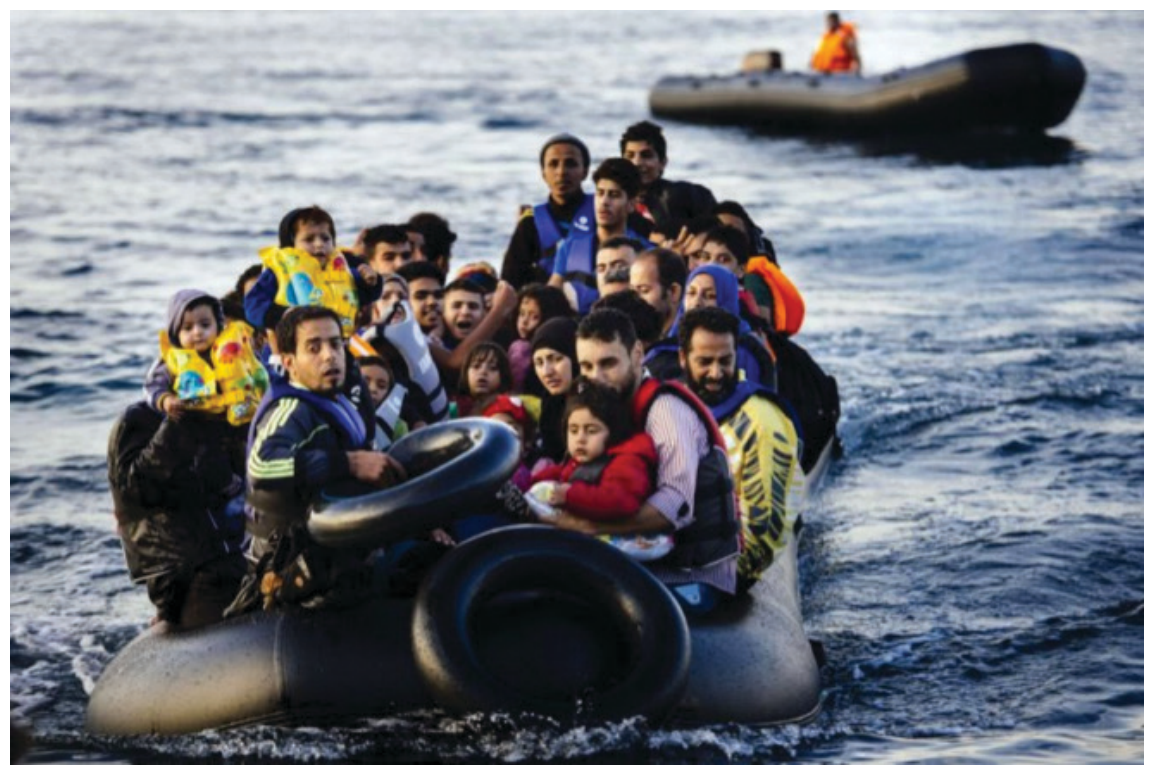

Um barco semelhante ao da figura anterior está na Figura 12, mas desta vez retratado muito próximo, de maneira que se veem detalhes dos ocupantes. São adultos e crianças aglomerados em um pequeno espaço, sem ser possível quantificá-los. 0 grupo acaba atuando como vetor único, através do olhar, pois todos olham para uma mesma direção. Não há interação por contato (olhar) entre representados e espectador, mas a atitude (ângulo frontal do retrato, cores vivas, nível dos olhos) e a distância (enquadramento fechado) indicam certa afinidade em nível interacional. 
Figura 13. Refugiados e migrantes que desembarcaram na ilha de Lesbos, na Grécia, foram transportados para Atenas. Por: Alkis Konstantinidis/Reuters.

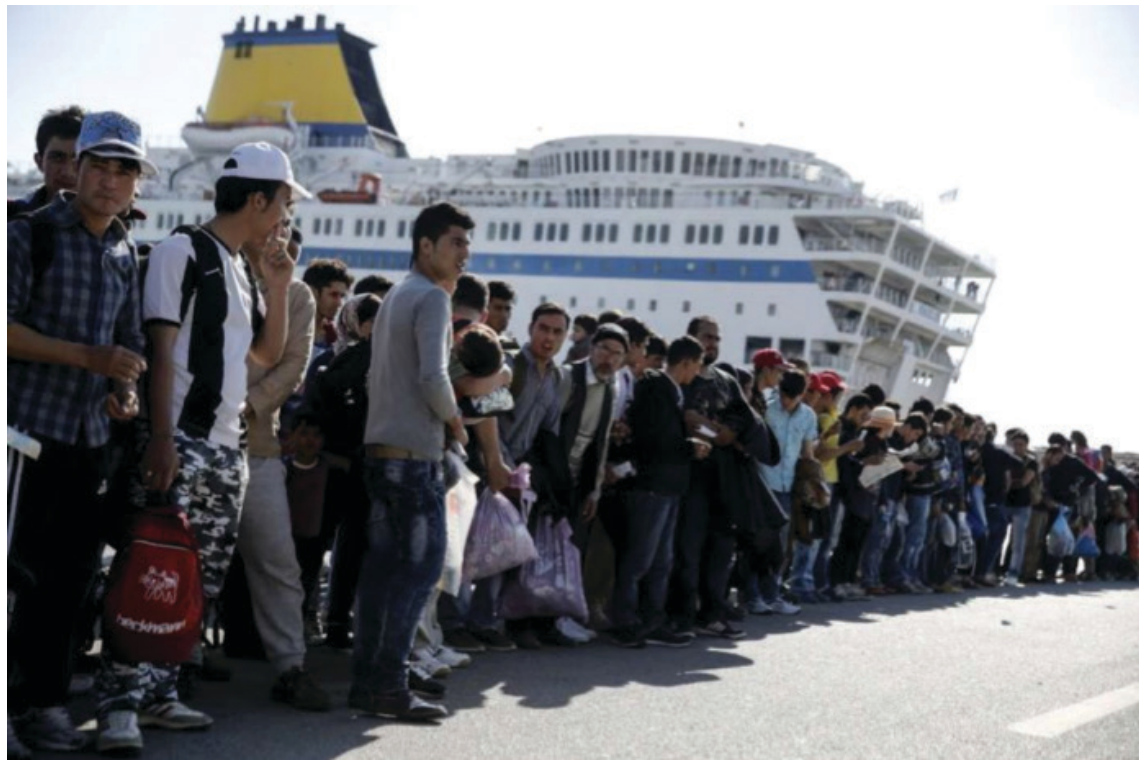

São muitos os refugiados retratados na Figura 13. Alguns poucos olham para 0 produtor da imagem, outros direcionam o olhar ao lado direito. Pode-se dizer que 0 ator da foto é o indivíduo na extrema esquerda, pois este olha para a câmera, está em primeiro plano e focado. Ele é quem estabelece a interação ator-espectador. Mais uma vez nota-se a representação dos refugiados diante de um barco enorme, reforçando a fragilidade e o caráter passageiro, transitório, nômade a eles associados.

\section{Conclusões}

A partir da análise de 13 imagens publicadas pelo jornal Público online, percebem-se padrões de retratação dos refugiados, mas também foram vistos casos particulares interessantes. Os casos singulares destacados são aqueles nas Figuras 6 e 8, nas quais um único indivíduo aparecia como ator, estando ele sozinho ou não na imagem. Nesses casos veem-se rostos, emoções e reflete-se sobre o contexto em que a pessoa retratada está inserida.

Sobre padrões identificáveis entre as fotos podem ser elencados: a) situações de subordinação; b) uso da cor como fator de diferenciação ou união; c) imagens que mostram barcos e avião; d) ação ou olhar de um grupo a direcionar o espectador. 0 primeiro caso lembra as Figuras 1 e 4, onde foram reconhecidos episódios em que houve subordinação dos atores retratados, agindo estes tanto como subordinados como subordinadores.

0 uso da cor para diferenciar ou unir elementos foi um recurso usado, por exemplo, nas Figuras 1, 4 e 10. No primeiro, os tons de cores vivas foram usados para destacar os dois atores da foto diante do grande grupo ao seu redor; nos demais, houve a monocromia em tons escuros a fim de unificar os refugiados em um único 
grupo. 0 item "c" traz a situação mais frequentemente identificada: a presença de barcos e avião nas imagens (Figuras 7, 8, 9, 10, 11, 12 e 13), reforçando o caráter transitório dos refugiados e lembrando a condição de nomadismo a que se submetem em busca de uma nova vida.

Por fim, 0 item " $d$ " diz respeito às imagens nas quais o espectador não tem contato visual com o retratado, mas tem seu olhar direcionado por ele (seja indivíduo ou grupo), através de uma ação coletiva. É o que se nota nas Figuras $2,5,11,12$ e 13. Em todos os casos, o ponto em comum é que o que influencia o olhar do espectador é o fato de se ter um grande número de retratados a fazer a mesma ação, como andar em certa direção ou olhar para certo lado, o que possivelmente não teria efeito se fosse uma ação individual.

0 estudo das 13 imagens mostra que há uma recorrente representação dos refugiados como grupos, e não indivíduos, nômades, em situação de risco e subordinação. Conclui-se, portanto, que de um modo geral, as fotografias utilizadas pelo jornal Público nas matérias online analisadas endossam o que autores como Augé (1997), Canclini (1998) e Mattelart (1999) problematizam sobre a identidade do "outro" nos media. São repetidos esquemas de representação que tendem a reduzir a compreensão do refugiado como alguém em constante deslocamento, muitas vezes em situação de risco ou más condições. Poucas vezes foram percebidas situações em que se tem pistas sobre a identidade do retratado: destaca-se a Figura 1, onde as mulheres vestem véus que indicam caráter religioso, por exemplo. Contudo, deve-se também ressaltar Figuras como a 6 e a 8, nas quais o plano fechado, o foco e a centralidade dos refugiados retratados permitem ao espectador uma melhor reflexão sobre quem ele vê.

\section{REFERÊNCIAS BIBLIOGRÁFICAS}

Acnur (2000). A Situação dos Refugiados no Mundo - cinquenta anos de ação humanitária. Tradução de Isabel Galvão. Almada/Portugal: Artes Gráficas.

Atanasovski, R. (2015). AFP. [Figura] Recuperado de: https://www.publico.pt/2015/10/04/ mundo/noticia/cerca-de-630-mil-migrantes-entraram-ilegalmente-na-europa-desde-janeiro-1710061 Acesso em 28/02/2017

Augé, M. (1998). Hacia una Antropología de los Mundos Contemporaneos. Barcelona: Gedisa, 2 ed.

Barbosa, M. (2012). Nós e eles: responsabilidade social dos média na construção de uma cidadania culturalmente inclusiva. Comunicação e Sociedade 21: 231-240.

Behrakis, Y. (2015). Reuters. [Figura] Recuperado de: https://www.publico.pt/2015/10/08/ mundo/noticia/crise-migratoria-na-mira-do-nobel-da-paz-mas-ainda-se-aceitam-apostas-1710507 Acesso em 28/02/2017

Buriham, M. L (2015). Propuesta metodológica para estudiar el contenido periodístico. Estudio de caso de la crisis de los refugiados en la prensa española. In: Portal de la Comunicación InCom-UAB. Disponível em http://www.portalcomunicacion.com/monograficos_det. asp?id=345 Acesso em 28 de agosto de 2016. Acesso em 28/02/2017

Canclini, N. G. (1998). América Latina entre Europa y Estados Unidos: mercado e interculturalidad. Halle (Alemanha), (Conferência apresentada no II Congresso Europeo de Latinoamericanistas). 
Dilkoff, D. (2015). AFP. [Figura] Recuperado de: https://www.publico.pt/2015/10/10/mundo/noticia/alemanha-e-ue-querem-novo-imposto-para-financiar-apoio-aos-refugiados-1710756 Acesso em 28/02/2017

Dilkoff, D. (2015). AFP. [Figura] Recuperado de: https://www.publico.pt/2015/10/14/mundo/ noticia/atenas-rejeita-cooperacao-militar-com-a-turquia-no-mar-egeu-para-travar-refugiados-1711149 Acesso em 28/02/2017

Dilkoff, D. (2015). AFP. [Figura] Recuperado de: https://www.publico.pt/2015/10/15/mundo/noticia/ue-vai-anunciar-mais-medidas-externas-para-travar-a-crise-dos-refugiados-1711215 Acesso em 28/02/2017

González-Cortés, M.E. (2006). La Construcción de la Realidad en los Procesos Migratórios, Málaga: Associación para la Investigación y el Desarrollo de la Comunicación.

Konstantinidis, A. (2015). Reuters. [Figura] Recuperado de: https://www.publico. pt/2015/10/15/mundo/noticia/europa-discute-concessoes-a-turquia-para-fechar-plano-de-accao-1711318 Acesso em 28/02/2017

Kress, G. \& van Leeuwen, T. (1996). Reading Images: The Grammar of Visual Design (2nd ed.), Victoria: Deakin University.

Kress, G. \& van Leeuwen, T. (2006). Reading Images: The Grammar of Visual Design (2nd ed.), London: Routledge.

McLuhan, M., Fiore, Q., \& Agel, J. (1968). War and peace in the global village (Vol. 127). New York: Bantam books.

Messinis, A. (2015). AFP. [Figura] Recuperado de: https://www.publico.pt/2015/10/06/ mundo/noticia/ue-paga-a-turquia-para-tentar-travar-os-milhoes-de-refugiados-da-siria-1710309 Acesso em 28/02/2017

Messinis, A. (2015). AFP. [Figura] Recuperado de: https://www.publico.pt/2015/10/09/ mundo/noticia/bebe-de-um-ano-encontrado-morto-num-barco-de-refugiados-em-lesbos-1710600 Acesso em 28/02/2017

Nimani, A. (2015). AFP. [Figura] Recuperado de: https://www.publico.pt/2015/10/01/mundo/noticia/podem-chegar-a-europa-14-milhoes-de-refugiados-entre-2015-e-2016-diz-onu-1709749 Acesso em 28/02/2017

Rossignol, P. (2015). Reuters [Figura] Recuperado de: https://www.publico.pt/2015/10/03/ mundo/noticia/mais-de-uma-centena-de-migrantes-forca-intrusao-no-tunel-da-mancha-1709969 Acesso em 28/02/2017

Ruvic, D. (2015). Reuters. [Figura] Recuperado de: https://www.publico.pt/2015/10/07/ mundo/noticia/para-compensar-o-envelhecimento-dos-paises-ricos-abram-portas-aos-imigrantes-1710449 Acesso em 28/02/2017

Silveirinha, M. J., \& Cristo, A. T. P. D. (2004). A construção discursiva dos imigrantes na imprensa. Revista Crítica de Ciências Sociais 69: 117-137.

Silvestre, F. C. L. F. (2011). Um olhar sobre a imprensa: representações sobre os requerentes de asilo e refugiados em Portugal. Dissertação de Mestrado. Faculdade de Ciências Sociais e Humanas, Universidade Nova de Lisboa.

Solaro, A. (2015). AFP. [Figura] Recuperado de: https://www.publico.pt/2015/10/09/mundo/noticia/partilha-de-refugiados-na-ue-comeca-com-19-eritreus-a-caminho-da-suecia-1710632 Acesso em 28/02/2017 
United Nations High Commissioner For Refugees (UNHCR). (2015). Global Trends 2014: World at War. Genebra: UNHCR. Disponível em http://unhcr.org/556725e69.html Acesso em 28/02/2017

Zitouny, I. (2015). Reuters. [Figura] Recuperado de: https://www.publico.pt/2015/10/08/ mundo/noticia/uniao-europeia-reforca-medidas-de-repatriamento-de-migrante-economicos-1710546 Acesso em 28/02/2017

Marina Empinotti - Doutoranda em Estudos da Comunicação FCT - Universidade da Beira Interior (UBI)

Data de recepção do artigo/ Received for publication: 02.11.2016

Data de aceitação do artigo/ Accepted in revised form: 28.02.2017 